\title{
Time course of enzyme induction in rifampicin-warfarin interaction: A case report
}

\section{Bee Ling Kelly Chng, Jin Shing Hon, Elicia Purnata, Chi Keong Ching}

\begin{abstract}
Introduction: Concomitant administration of rifampicin and warfarin poses a challenge in achieving stable therapeutic international normalised ratio (INR). There is no published case report in Singapore to show the time course for enzyme induction and de-induction in Asian patient. Case Report: A 90-year-old man was on a stable warfarin dose of $1.5 \mathrm{mg}$ daily for stroke prevention in atrial fibrillation with therapeutic INR before switching to rivaroxaban and subsequently apixaban. He was initiated with a 9-month course of rifampicin, isoniazid, pyridoxine and ethambutol for treatment of pulmonary tuberculosis. Hence, apixaban was switched back to warfarin. Therapeutic INR was first achieved 20 days after a dose increment of $166 \%$ in warfarin from $1.5 \mathrm{mg}$ daily to $4 \mathrm{mg}$ daily. The INR subsequently decreased again and warfarin dose was increased to $4.5 \mathrm{mg}$ daily. A 2-fold increment in warfarin dose was required to reach the second therapeutic INR at week-7. INR was stable in therapeutic range with $4.5 \mathrm{mg}$ daily and patient was followed up every 2 to 4 weeks. Time in therapeutic range (TTR) was $74 \%$ over the course of nine months. After five days of discontinuing rifampicin, INR decreased to 1.70 despite maintaining the same dose of warfarin. Conclusion: The total time course of enzyme induction takes about six to seven weeks to reach a steady state. The
\end{abstract}

Bee Ling Kelly Chng ${ }^{1}$, Jin Shing Hon ${ }^{1}$, Elicia Purnata ${ }^{1}$, Chi Keong Ching ${ }^{2}$

Affiliations: ${ }^{1}$ Department of Pharmacy, National Heart Centre, Singapore; ${ }^{2}$ Department of Cardiology, National Heart Centre, Singapore.

Corresponding Author: Bee Ling Kelly Chng, National Heart Centre, Singapore; Email: kelly.chng.b.I@nhcs.com.sg

Received: 15 May 2018

Accepted: 18 June 2018

Published: 04 July 2018 de-induction of enzyme may not occur within the first week of rifampicin discontinuation. Close INR monitoring during the initial phase of initiation or termination of rifampicin is required.

Keywords: Enzyme induction, Interaction, Rifampicin, Time Course, Warfarin

\section{How to cite this article}

Chng BLK, Hon JS, Purnata E, Ching CK. Time course of enzyme induction in rifampicin-warfarin interaction: A case report. Int J Case Rep Images 2018;9:100931Zo1BC2018.

Article ID: 100931Zo1BC2018

$* * * * * * * * *$

doi: 10.5348/100931Z01BC2018CR

\section{INTRODUCTION}

The World Health Organization (WHO) reported that Tuberculosis (TB) remains one of the major public health concerns in the South-East Asia Region with steadily increasing TB cases [1]. Rifampicin is one of the widely used first-line drugs for the treatment of tuberculosis and commonly used to treat other infections such as meningitis, osteomyelitis and endocarditis besides tuberculosis [2]. However, rifampicin can induce multiple enzymes responsible for drug metabolism such as cytochrome $\mathrm{P} 450$ (CYP) 2C9, CYP 3A4, CYP 2C19, CYP 1A2, other detoxification pathways and several drug transporters like P-glycoprotein [3]. Direct oral anticoagulants such as apixaban and rivaroxaban are metabolized via CYP 3A4. Therefore, rifampicin use is contra-indicated in patients on rivaroxaban and apixaban because it increases metabolism of rivaroxaban and apixaban, reducing their anticoagulation efficacy and puts patient at higher risk of thromboembolic events. 


\section{EDORiUM Journals}

Although warfarin is also metabolized via CYP $2 \mathrm{C} 9$ and CYP $3 \mathrm{~A} 4$, it can be used together with rifampicin with appropriate dosage titration to achieve therapeutic international normalised ratio (INR). Therefore warfarin remains the drug of choice for patient with atrial fibrillation and requiring rifampicin. Several case reports showed challenges and difficulty to achieve therapeutic INR when rifampicin was co-administered with warfarin [4-8]. In addition, there is no published case report in Singapore to show the time course for enzyme induction and de-induction in Asian patient.

This case report demonstrates the dosage increment required and time course for enzyme induction between warfarin and rifampicin in a patient with atrial fibrillation who developed tuberculosis.

\section{CASE REPORT}

A 90-year-old Chinese man with a history of hypertension, hyperlipidaemia, ischaemic heart disease, atrial myxoma, paroxysmal atrial fibrillation, transient ischaemic attack, chronic kidney disease and gout was on a stable warfarin dose of $1.5 \mathrm{mg}$ per day. Patient's INR reading was within therapeutic INR range (2.0 to 3.0) for two years. Warfarin was switched to rivaroxaban 15 mg daily on 15 April 2015 and subsequently replaced by apixaban $2.5 \mathrm{mg}$ twice daily on 1 December 2016 when his renal function deteriorate during inpatient admission as apixaban is less renally cleared. His concurrent medications were apixaban $2.5 \mathrm{mg}$ twice daily, bisoprolol $5 \mathrm{mg}$ daily, valsartan $80 \mathrm{mg}$ daily, simvastatin $20 \mathrm{mg}$ at night and colchicine 500 mcg twice daily when necessary.

He developed pulmonary tuberculosis (PTB) on 15 December 2016 and was given rifampicin $600 \mathrm{mg}$ daily, isoniazid $300 \mathrm{mg}$ daily, pyridoxine $20 \mathrm{mg}$ daily and ethambutol $1000 \mathrm{mg}$ three times a week. Rifampicin can reduce blood concentration of apixaban that may reduce effectiveness of apixaban for stroke prevention [9]. Therefore, apixaban was switched to warfarin with a plan to up-titrate warfarin dose weekly until his INR is therapeutic.

As shown in Table 1, patient was loaded with warfarin $2 \mathrm{mg}$ once daily for three days on 16 December 2016. Patient was then continued on $1.5 \mathrm{mg}$ once daily for two days. He remained sub-therapeutic with INR 1.20 despite warfarin dose increment for three weeks. Therefore, a different approach using larger dose increment with closer monitoring every three to four days was chosen. INR increased from 1.20 to 2.10 in four days after dose was increased to $4 \mathrm{mg}$ daily ( $87 \%$ daily dose increment). Due to this drastic increased in INR, warfarin dose was decreased to $3 \mathrm{mg}$ once daily. INR decreased to 1.80 after three days and dose was then increased to $3.5 \mathrm{mg}$ per day for four days. Even though INR was 1.90 after four days, the same dose was maintained. Subsequently, patient's INR decreased to 1.50. Hence, patient was loaded with one dose of warfarin $5 \mathrm{mg}$ and then up-titrated to $4.5 \mathrm{mg}$
Table 1: Summary of warfarin dose titration

\begin{tabular}{|c|c|c|c|c|}
\hline Day & $\begin{array}{l}\text { Previous } \\
\text { warfarin } \\
\text { dose }\end{array}$ & INR & $\begin{array}{l}\text { Warfarin } \\
\text { dose changes }\end{array}$ & $\begin{array}{l}\% \text { dose } \\
\text { change }\end{array}$ \\
\hline Day 5 & $\begin{array}{l}2 \text { mg daily } \\
\text { for three } \\
\text { days from } 16 \\
\text { December } \\
2016 \text { (Day } 1 \text { ); } \\
\text { then } 1.5 \mathrm{mg} \\
\text { daily for two } \\
\text { days }\end{array}$ & 1.60 & $2 \mathrm{mg}$ daily & $+33 \%$ \\
\hline Day 14 & $2 \mathrm{mg}$ daily & 1.20 & $\begin{array}{l}2 \text { mg } 5 \text { times/ } \\
\text { week; } \\
2.5 \mathrm{mg} 2 \\
\text { times/ week }\end{array}$ & $+7 \%$ \\
\hline Day 21 & $\begin{array}{l}2 \mathrm{mg} 5 \text { times/ } \\
\text { week; } 2.5 \mathrm{mg} 2 \\
\text { times/week }\end{array}$ & 1.20 & 4 mg daily & $+87 \%$ \\
\hline Day 25 & 4 mg daily & 2.10 & $3 \mathrm{mg}$ daily & $-25 \%$ \\
\hline Day 28 & $3 \mathrm{mg}$ daily & 1.80 & $3.5 \mathrm{mg}$ daily & $+17 \%$ \\
\hline Day 32 & $3.5 \mathrm{mg}$ daily & 1.90 & Same & O\% \\
\hline Day 38 & $3.5 \mathrm{mg}$ daily & 1.50 & $\begin{array}{l}5 \mathrm{mg} \text { for } 1 \text { day; } \\
4.5 \mathrm{mg} \text { daily }\end{array}$ & $+29 \%$ \\
\hline Day 41 & $4.5 \mathrm{mg}$ daily & 1.90 & Same & O\% \\
\hline Day 49 & $4.5 \mathrm{mg}$ daily & 2.40 & Same & $0 \%$ \\
\hline Day 56 & $4.5 \mathrm{mg}$ daily & 2.50 & Same & $0 \%$ \\
\hline Day 70 & $4.5 \mathrm{mg}$ daily & 2.00 & Same & $0 \%$ \\
\hline Day 98 & $4.5 \mathrm{mg}$ daily & 2.10 & Same & O\% \\
\hline $\begin{array}{l}\text { Day } \\
124\end{array}$ & $4.5 \mathrm{mg}$ daily & 1.98 & $\begin{array}{l}4 \text { mg } 3 \text { times/ } \\
\text { week; } 5 \text { mg } 4 \\
\text { times/ week }\end{array}$ & $+1.6 \%$ \\
\hline Day 153 & $\begin{array}{l}4 \text { mg } 3 \text { times/ } \\
\text { week; } 5 \text { mg } 4 \\
\text { times/week }\end{array}$ & 2.10 & Same & O\% \\
\hline $\begin{array}{l}\text { Day } \\
209\end{array}$ & $\begin{array}{l}4 \text { mg } 3 \text { times/ } \\
\text { week; } 5 \text { mg } 4 \\
\text { times/week }\end{array}$ & 2.30 & Same & o\% \\
\hline $\begin{array}{l}\text { Day } \\
264\end{array}$ & $\begin{array}{l}4 \text { mg } 3 \text { times/ } \\
\text { week; } 5 \text { mg } 4 \\
\text { times/week }\end{array}$ & 1.92 & Same & o\% \\
\hline $\begin{array}{l}\text { Day } \\
278\end{array}$ & $\begin{array}{l}4 \text { mg } 3 \text { times/ } \\
\text { week; } 5 \text { mg } 4 \\
\text { times/week }\end{array}$ & 1.70 & $\begin{array}{l}\text { Warfarin } \\
\text { stopped and } \\
\text { replaced with } \\
\text { rivaroxaban } \\
15 \text { mg daily. } \\
\text { Rifampicin } \\
\text { (15 December } \\
2016 \text { to } 15 \\
\text { September } \\
\text { 2017) was } \\
\text { stopped at day- } \\
\text { 273. }\end{array}$ & \\
\hline
\end{tabular}




\section{EDORiUM Journals}

daily for three days. Therapeutic INR was finally achieved in week-7 with warfarin dose of $4.5 \mathrm{mg}$ daily, a two-fold increment of warfarin dose. There was a slight increment of warfarin dose (1.6\%) when INR dropped to 1.98 at day124.

After concomitant administration of rifampicin and warfarin, therapeutic INR was first achieved in 20 days (Figure 1). When INR became subtherapeutic after that, it took another 24 days to reach therapeutic range (Figure 1). Time in therapeutic range (TTR) was $74 \%$ over the 9-month course.

Rifampicin was discontinued on day-273. After 5 days of rifampicin discontinuation, INR dropped to 1.70 despite patient taking the same dosage of warfarin. The INR trend post rifampicin cessation was not stipulated in detail because warfarin was switched to rivaroxaban 15 mg daily five days after rifampicin was stopped.

Patient was compliant to the medications throughout the nine months course of concomitant rifampicin and warfarin. There were no changes in the lifestyle or medications.His liver function and renal function were stable.

\section{DISCUSSION}

It is challenging to predict a patient's response to warfarin and the dosage adjustment required when pulmonary tuberculosis medications especially rifampicin is initiated or discontinued. There are few studies publishing the magnitude of dosage adjustment required when there is drug-drug interaction involving rifampicin and warfarin and majority of the studies showed challenges in anticoagulation management [48].

Martins et al (2013) described a 59-year-old Brazilian woman treated with warfarin for stroke prevention in atrial fibrillation requiring a three months sequential increases of warfarin dosage from $45 \mathrm{mg}$ per week to 80 mg per week to reach therapeutic INR. Warfarin dosage

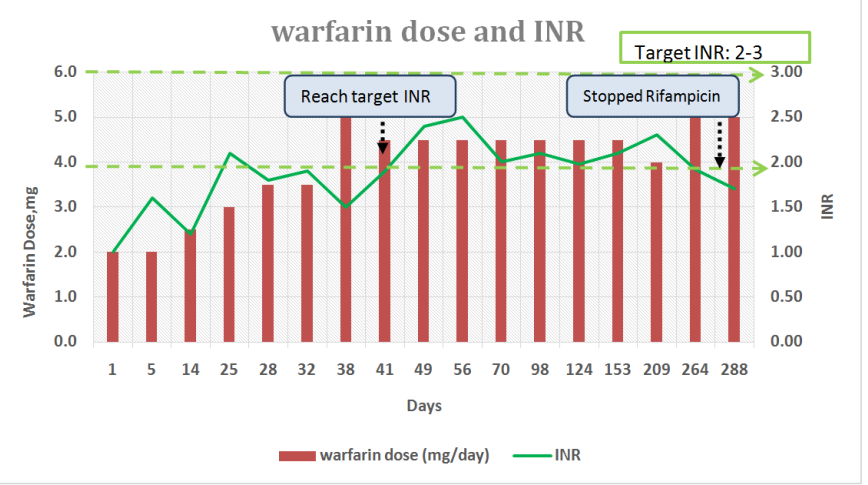

Figure 1: Warfarin dose and INR during concomitant administration of rifampicin and warfarin. had to be doubled at the beginning of rifampicin therapy [10].

Our case report showed that therapeutic INR can be achieved within a shorter period of seven weeks with frequent INR monitoring every three to four days and a higher dosage adjustment. A 200\% of dose increment was required to attain therapeutic INR over seven weeks.

INR reducing from 1.90 to 1.50 with the same warfarin dosage of $3.5 \mathrm{mg}$ daily on the 5 th week of concomitant rifampicin and warfarin suggested the possibility of rifampicin inducing enzymes in a gradual pattern by phases. Our finding estimated that the time course of induction most likely reach a steady state by week-7 of concomitant interacting drugs administration. Although rifampicin has a half-life elimination of about 3 to 4 hours, the time required to produce maximum enzyme induction is much longer because of the requirement of producing additional enzymes [3].

We expected to see an up-trending of INR after stopping rifampicin, but in contrast, we observed a drop in INR to 1.70 despite continuing the same dosage of warfarin. This indicates that a dose reduction of warfarin may not be required within the first week of stopping rifampicin but frequent INR monitoring is required. Jessica Dawson (2016) also reported a drop of INR from 2.50 to 1.50 with empirically dose reduction of $14 \%$ (from $35 \mathrm{mg}$ per day to $30 \mathrm{mg}$ per day) after five days discontinuation of rifampicin [11].

The time course of de-induction remains complex and poorly understood. The de-induction of the enzymes may happen gradually when the enzyme-inducing drug is stopped. The de-induction of hepatic enzymes not only depends on elimination of the inducing agent but also the natural degradation time of the enzymes [3].

Meanwhile, we suggest a higher dosage increment with close INR monitoring in three to five days during the co-administration of warfarin and rifampicin so that therapeutic INR can be achieved within shorter period of time. We were unable to observe the INR trend after rifampicin was stopped as warfarin was switched to rivaroxaban subsequently. Should the patient be continued on warfarin after the completion of rifampicin, every three to seven days monitoring of INR for the first four weeks of rifampicin discontinuation is recommended to prevent incidence of thromboembolic events and bleeding complications.

\section{CONCLUSION}

Rifampicin induces enzymes gradually by phases. The total time course of enzyme induction takes about six to seven weeks to reach a steady state. Immediate warfarin dose reduction is not necessary as the deinduction of enzyme may not occur within the first week of discontinuation. Close INR monitoring during the initial phase of initiation or termination of rifampicin is required. Further studies can be conducted to investigate 
the prolonged onset and offset of interactions so that the interaction duration can be better predicted.

\section{REFERENCES}

1. World Health Organization, Regional office for SouthEast Asia. Tuberculosis control in the South-East Asia Region: Annual report 2015. [Available at: http:// apps.who.int/iris/handle/10665/154550]

2. Baciewicz AM, Chrisman CR, Finch CK, Self TH. Update on rifampin and rifabutin drug interactions. Am J Med Sci 2008 Feb;335(2):126-36.

3. Horn JR, Hansten PD. Time course for enzyme induction and deinduction. Pharm Times 2011.

4. Fahmi AM, Abdelsamad O, Elewa H. Rifampinwarfarin interaction in a mitral valve replacement patient receiving rifampin for infective endocarditis: A case report. Springerplus 2016 Jan 4;5:8.

5. Jha SC. To achieve target international normalized ratio with concurrent warfarin and rifampicin therapy is a challenge: A case report and review of literature. Int J Res Dermatol 2015 Dec;1(1):17-9.

6. Krajewski KC. Inability to achieve a therapeutic INR value while on concurrent warfarin and rifampin. $J$ Clin Pharmacol 2010 Jun;50(6):710-3.

7. Kim KY, Epplen K, Foruhari F, Alexandropoulos H. Update on the interaction of rifampin and warfarin. Prog Cardiovasc Nurs 2007;22(2):97-100.

8. Lee CR, Thrasher KA. Difficulties in anticoagulation management during coadministration of warfarin and rifampin. Pharmacotherapy 2001 Oct;21(10):1240-6.

9. Vakkalagadda B, Frost C, Byon W, et al. Effect of rifampin on the pharmacokinetics of apixaban, an oral direct inhibitor of factor xa. Am J Cardiovasc Drugs 2016 Apr;16(2):119-27.

10. Martins MA, Reis AM, Sales MF, et al. Rifampicinwarfarin interaction leading to macroscopic hematuria: A case report and review of the literature. BMC Pharmacol Toxicol 2013 May 4;14:27.

11. Dawson J, Dedigama M, David JE, Sorich M, Mangoni AA, Rowland A. Prolonged induction of warfarin metabolism and a paradoxical INR response in a mitral valve replacement patient receiving rifampicin for infective endocarditis. Biomed R Clin Prac 2016 1(2)62-5.

\section{Author Contributions}

Bee Ling Kelly Chng - Substantial contributions to conception and design, Acquisition of data, Analysis and interpretation of data, Drafting the article, Revising it critically for important intellectual content, Final approval of the version to be published

Jin Shing Hon - Substantial contributions to conception and design, Analysis and interpretation of data, Revising it critically for important intellectual content, Final approval of the version to be published

Elicia Purnata - Acquisition of data, Analysis and interpretation of data, Drafting the article, Revising it critically for important intellectual content, Final approval of the version to be published

Chi Keong Ching - Analysis and interpretation of data, Drafting the article, Revising it critically for important intellectual content, Final approval of the version to be published

\section{Guarantor of Submission}

The corresponding author is the guarantor of submission.

\section{Source of Support \\ None}

\section{Consent Statement}

Written informed consent was obtained from the patient for publication of this case report.

\section{Conflict of Interest}

Authors declare no conflict of interest.

\section{Copyright}

(C) 2018 Bee Ling Kelly Chng et al. This article is distributed under the terms of Creative Commons Attribution License which permits unrestricted use, distribution and reproduction in any medium provided the original author(s) and original publisher are properly credited. Please see the copyright policy on the journal website for more information.
Access full text article on other devices

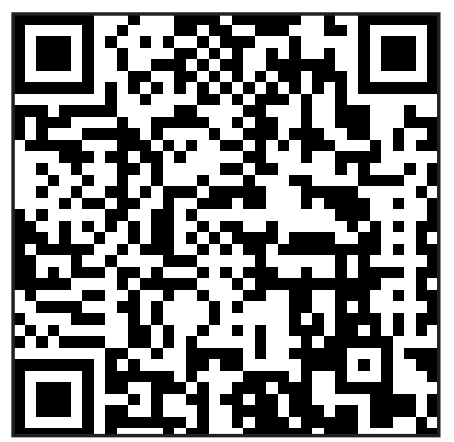

Access PDF of article on other devices

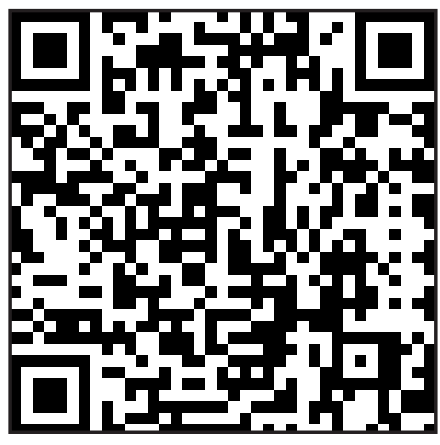

